\title{
Post-fire tree mortality in mixed forests of central Portugal
}

\author{
F.X. Catry ${ }^{1 *}$, F. Rego ${ }^{1}$, F. Moreira ${ }^{1}$, P.M. Fernandes ${ }^{2}$, J.G. Pausas ${ }^{3}$ \\ ${ }^{1}$ Centro de Ecologia Aplicada "Prof. Baeta Neves", Instituto Superior de Agronomia, Universidade Técnica de \\ Lisboa, Tapada da Ajuda, 1349-017 Lisboa, Portugal; Telephone: (351)213653333; Fax: (351)213623493; \\ ${ }^{2}$ Centro de Investigação e de Tecnologias Agro-Ambientais e Biológicas (CITAB), Universidade de Trás-os- \\ Montes e Alto Douro, Apartado 1013, 5001-801 Portugal; \\ ${ }^{3}$ Centro de Investigaciones sobre Desertificación (CIDE, CSIC), Apartado Oficial, ES-46470 Albal, Valencia, \\ Spain; \\ *Corresponding author (e-mail: fcatry@isa.utl.pt)
}

\begin{abstract}
Wildfires constitute a recurrent disturbance in the Mediterranean Basin. However, managers from this region confront with a lack of information on the effects of fire on most woody species, which is required for defining sustainable forest management strategies. Following a large wildfire in central Portugal (2003), we surveyed the area during the first year and assessed the vegetative condition of 1040 burned trees from 11 different species. Among those trees, 755 individuals were selected and monitored annually for four years. At the end of the study, almost all broadleaved trees survived, while most coniferous died. In spite of the low mortality observed in broadleaves, most were top-killed and regenerated only from basal resprouts, which implies a slow recovering process. Quercus suber, however, showed vigorous post-fire crown resprouting and was the most resilient species. We fitted logistic regression models to predict the probability of individual tree mortality and top-kill from fire severity indicators and tree characteristics. Besides the differences between the two main functional groups (coniferous, broadleaved), bole char height and crown volume scorched or consumed were important predictors of tree responses. Additionally, the main factor determining crown mortality on broadleaved species was bark thickness. The selected models performed well when tested with independent data obtained on four other wildfires. These models have several potential applications and can be useful to managers making pre-fire or post-fire decisions in mixed forest stands in the western Mediterranean Basin
\end{abstract}

\section{Keywords}

Wildfires; fire effects; tree survival; modelling; Mediterranean ecosystems; resprouting 


\section{Introduction}

Wildfires constitute a recurrent disturbance in the Mediterranean Basin. Prediction of post-fire tree mortality and top-kill (i.e., crown mortality) is essential to plan logging or to evaluate recovery options (e.g. reforestation, wildlife habitat, soil erosion) in burned areas (Ryan et al., 1988; Regelbrugge and Conard, 1993). However, authorities and managers from the Mediterranean Basin confront with a lack of published information on the effects of wildfire on most woody species (e.g. Ordóñez et al., 2005), and especially on broadleaved ones. Even for European pines, which are relatively well studied, recent reviews indicate that most studies are based in low-intensity dormant season burns and only reflect short-term (1-2 years post-fire) mortality (Fernandes and Rigolot, 2007; Fernandes et al., 2008).

Much of the variation in plant response to burning can be attributed to varying sensitivity to heat of the different tissues and species. The time required to kill plant tissue decreases exponentially with the exposure time to a given temperature (Bond and van Wilgen, 1994). Tree resistance to fire depends largely on the presence of morphological traits that protects critical tissues and on the food reserves for successful recovery (Whelan, 1995; DeBano et al., 1998). The tissues important for post-fire recovery can be protected from lethal temperatures in several ways; for instance, cambium and stem buds may be protected from radiant heat by a thick bark, while below-ground stems and buds may be shielded by the overlaying soil (Whelan, 1995; DeBano et al., 1998). Fire injury on trees includes crown-kill, bole-kill and root-kill, crown damage being the most readily observed whereas root injury is seldom quantified. Variables such as bole char height and the percentage of crown scorched or consumed are often used as tree-level fire severity descriptors (e.g. Peterson 1985; Stephens and Finney, 2002).

Crown injury has been identified as the primary cause of post-fire mortality in most conifers (e.g. Ryan and Reinhardt, 1988; Rigolot, 2004) but the response to defoliation by fire varies considerably among species. Many species are extremely sensitive and are killed if defoliation is above some threshold value, while others although completely defoliated will regenerate the crown by issuing shoots from epicormic (Bond and van Wilgen, 1994) or leaf buds (e.g. Thies et al., 2006).

Bole damage consists of injury to phloem, cambium, or functional xylem (Ryan, 1998), and has been correlated with tree mortality and top-kill through the use of parameters like bark thickness, bole diameter, bole char height or char depth (Regelbrugge and Conard, 1993; Hély et al., 2003; McHugh and Kolb, 2003). Bark thickness has been a widely employed morphological variable to account for fire resistance (Peterson and Ryan, 1986; Pausas 1997; Rigolot, 2004), as small differences in bark thickness produce large differences in fire resistance (Bond and van Wilgen, 1994; Moreira et al. 2007). The time taken for cambial cells to reach lethal temperature is a function of both bark thickness and thermal properties of the bark, although the former plays a more important role (Hare, 1965; Peterson and Ryan, 1986).

Post-fire tree survival and regeneration capacity are mainly influenced by factors related to both fire severity and individual tree characteristics, although additional factors of stress in the post-fire environment like drought, herbivory or pests can also be relevant (Whelan, 1995; DeBano et al., 1998; Miller, 2000; McHugh and Kolb, 2003; Dylan et al., 2006).

In this paper we hypothesize that the most important factors determining the initial and delayed tree mortality and top-kill in Mediterranean mixed forests are fire severity, and bark thickness or tree size; because closely related plants tend to share similar traits, we also predict that the differences within taxonomic group (coniferous, broadleaved) will be lower than between groups. Higher mortality is expected in trees apparently more injured by fire, on smaller or thinner barked individuals, and in coniferous rather than in broadleaved species, because most species from the former group are not able to resprout when the entire canopy is 
burned. Ungulate herbivory is also hypothesized to be an additional factor of stress affecting delayed mortality in top-killed broadleaves. A large wildfire which occurred in 2003 in a mixed forest of central-west Portugal provided an opportunity to evaluate these hypotheses in a range of tree species affected by the same fire and under the same ecological conditions. The study includes species for which there was no previous information on post-fire responses.

\section{Methods}

\subsection{Study area}

The study area ( 885 ha) is located in central-west Portugal (western Iberian Peninsula), 8 $\mathrm{km}$ from the sea, in a public fenced area (Tapada Nacional de Mafra). Elevation ranges from 80 to $360 \mathrm{~m}$ and soils are predominantly humic cambisols derived from sandstone. Climate is Mediterranean, with a mean annual precipitation of $850-950 \mathrm{~mm}$ and a mean annual temperature ranging from 13 to $15{ }^{\circ} \mathrm{C}$ (IA, 2003). Before the fire, the vegetation was dominated mainly by forests (48\%), including both broadleaved and coniferous species, and by shrublands $(46 \%)$.

\subsection{Sampling and measurements}

In September $2003,70 \%$ of the study area burned in a large wildfire that totaled about 2800 ha. Fire weather was extreme and the crown of most trees was affected, although in different degrees. Following the fire, the study area was mapped and divided into a regular 500-m grid using GIS (geographic information systems), and 20 points (centers of each grid) were randomly selected in the burned area as starting locations for field plots. Points that fell in treeless areas were moved to the nearest burned forest stand. Each plot was about 100-m long and 20-m wide, and all trees found within it were coded, marked and geographically located (with both GPS and terrain measurements) for monitoring in the subsequent years. Elevation, aspect and slope were derived for each tree location from a digital elevation model at 1:10,000 scale. We did not sample trees with broken stems or identified as being already dead before the fire (evaluation based e.g. on bark condition or advanced degree of decay).

The first field sampling was performed three months after the fire (December 2003) and included 1040 burned trees of 11 of the more representative species in the area over a range of tree sizes that were differently affected by fire (Table 1). The studied species were: Castanea sativa Mill. (chestnut), Crataegus monogyna Jacq. (weissdorn), Eucalyptus globulus Labill. (bluegum eucalyptus), Fraxinus angustifolia Vahl. (narrowleaf ash), Olea europaea L. var. sylvestris Brot. (wild olive), Pinus pinaster Ait. (maritime pine), Pinus pinea L. (umbrella pine), Pistacia lentiscus L. (evergreen pistache), Quercus coccifera L. (kermes oak), Quercus faginea Lam. ssp. broteroi (Portuguese oak), and Quercus suber L. (cork oak). All the studied broadleaved species are resprouters and the coniferous species are non-resprouters (Paula et al. 2009). Most of the studied species have a wide distribution in the Mediterranean Basin and are within their natural area of distribution, except E. globulus (introduced species native to southeast Australia). In the study area $C$. sativa can be also considered as an introduced species (González, 2001; Krebs et al. 2004).

For each tree we recorded diameter at breast height (DBH, measured at $1.30 \mathrm{~m}$ above ground to the nearest $1 \mathrm{~cm})$, total tree height $(\mathrm{TH}$, measured with a hypsometer to the nearest $0.5 \mathrm{~m}$ ), and vegetative status (dead or alive) and type of regeneration (crown, basal). Trees were considered alive whenever green foliage was present regardless of its location on the tree, and were considered top-killed if they had no green foliage in the crown but exhibited 
basal or root sprouts. For $Q$. suber trees we also measured the bark thickness (BT) at breast height with a bark gauge. We averaged two measurements at opposite sides of the trunk $(\mathrm{N}-$ $\mathrm{S}$ ); in case of fissured bark the measurements were taken on bark "ridges" and therefore represent maximum BT. For the other 10 species, BT was not measured on burned trees because many had the bark severely affected by the fire. Alternatively we measured BT and DBH on 415 unburned trees within the study area (minimum 40 trees of different sizes per species), and derived allometric equations relating BT with DBH (Table 2) to estimate BT for each burned trees (except $Q$. suber).

For each tree, the percentages of crown volume scorched (CVS) and crown volume consumed (CVC) were visually estimated with the help of binoculars to the nearest $5 \%$.Total crown volume damaged (TCD), was then derived as TCD $=$ CVS + CVC (McHugh and Kolb, 2003). Evidence of residual buds on branch tips was used to identify branches that supported foliage before the fire (McHugh and Kolb, 2003). Foliage scorch was defined by a change in colour as a result of the fire. Although some species initiated new foliage shortly after burning, it was easy to distinguish between pre-fire and post-fire leaves during the first months by their colour. Maximum bole char height $(\mathrm{CH})$, the vertical extent of trunk blackening, was measured as an alternative indicator of fire injury. Percentage of bole char height $(\mathrm{PCH})$ expressed $\mathrm{CH}$ in relation to total tree height. $\mathrm{PCH}$ was a safer indicator of fire severity for some broadleaved deciduous species as at the time of the initial assessment of trees (three months after the fire) they were unleafed, so TCD was probably overestimated.

Because of the presence of a population of wild herbivores in the area (density of 0.4 deer ha $^{-1}$; Nunes, 2004), constituted by Dama dama L. (fallow deer) and Cervus elaphus L. (red deer), several trees were protected from browsing to further evaluate potential cumulative impacts of herbivory on post-fire mortality and recovery. About half of the individuals (from seven broadleaved species) without crown sprouting but with basal regeneration were protected (in early 2004) using individual wire protectors. Thus the presence/absence of herbivory (i.e., unfenced/fenced tree) was also considered a variable. Some species were not protected, because of (i) lack of sprouting response ( $P$. pinaster and $P$. pinea), (ii) crown sprouting in all trees (Q. suber), and (iii) avoidance by deer (E. globulus).

A second assessment of the vegetative status and type of regeneration of the initially sampled trees $(n=1040)$ was performed one year after the fire. From this set, a subset of 755 individuals was assessed annually until 2007 (4 years post-fire).

\subsection{Data analysis}

The probability of individual tree mortality and crown mortality (top-kill) one year and four years after fire were modelled by using binary logistic regression (Hosmer and Lemeshow 1989). All the previously mentioned variables, including some interactions, were tested as independent variables. Since resistance to cambium injury increases with the square of the bark thickness (Peterson and Ryan, 1986; Rego and Rigolot, 1990), fire injury resistance is expected to increase roughly with the square of stem diameter (Ryan, 1998), thus both $\mathrm{BT}^{2}$ and $\mathrm{DBH}^{2}$ were also tested as independent variables. Squared $\mathrm{PCH}$ and CVS were also included, as some authors recognized their non-linear influence on tree survival (Peterson and Ryan, 1986; Ryan and Reinhardt, 1988). The independent variables were selected by forward stepwise selection, and were included in each model only when statistically significant $(P<0.05)$. When correlation between two variables was larger than 0.5 , only one of them was used in the model. The most correlated pairs of variables $(r>|0.5|$; Pearson correlation coefficient) were: DBH with BT $(r=0.86)$, DBH with TH $(r=0.68)$, CVS with CVC $(r=-0.84)$, CVC with TCD $(r=0.64)$, and CH with TH $(r=0.63)$. Comparisons between 
treatments (e.g. protected vs. non-protected trees) were based on chi-square statistics (Sokal and Rohlf 1987). All analyses were carried out using SPSS software (SPSS 2006).

\subsection{Model evaluation}

The overall model significance was assessed through the chi-square goodness-of-fit omnibus test. Model performance was assessed by calculating the area under the receiver operating characteristics (ROC) curve (Hosmer and Lemeshow 1989). The ROC method has advantages in assessing model performance in a threshold-independent fashion, being independent of prevalence (e.g. Manel et al. 2001). Usually AUC values of 0.5-0.7 are taken to indicate low accuracy, values of 0.7-0.9 indicate useful applications and values above 0.9 indicate high accuracy (Swets 1988). Models with different combinations of variables were also compared using the Akaike Information Criterion (AIC) (Burnham and Anderson, 2003), and the one with lowest AIC considered the more parsimonious. Several models were tested using the available variables, but only the most parsimonious ones are presented.

In the validation phase (see next section), the model predictive ability was also quantified through cross-classification tables, which are based on the comparison of observed and predicted events. For this purpose, a range of cut-off-points were used to convert event probability (mortality or top kill) to dichotomous (presence/absence) data in order to define optimal cut-off point, that is, the probability corresponding to equal sensitivity and specificity.

\subsection{Model validation}

Models were validated through an independent dataset, constituted by pooling information from 4 different 2006 wildfires that occurred in central west Portugal, collected in another study (70 to $110 \mathrm{~km}$ far from the Mafra site; Tujeira and Morgado, 2007). Porto-deMós wildfire occurred in Leiria district and burned about 3400 ha. Agroal, Atouguia and Vale Florido wildfires occurred in Santarém district and burned about 380, 280 and 250 ha, respectively. The altitude in the burned sites ranges from 80 to $600 \mathrm{~m}$ and the soils are predominantly rhodo-chromic luvisols and calcic cambisols. Climate is Mediterranean, with a mean annual precipitation of $700-1600 \mathrm{~mm}$, mean annual temperature ranging from 15 to 17.5 ${ }^{\circ} \mathrm{C}$ (IA, 2003).

The dataset included 945 trees of four species monitored in the Mafra wildfire $(P$. pinaster, E. globulus, Q. faginea and $Q$. suber). Tree and fire damage data was collected about one year following wildfire occurrence. The field methods used in these fires (details are given by Tujeira and Morgado, 2007) were similar to those described for the Mafra wildfire, except that crown volume damage (CSV, CVC, TCD) was not assessed. Bark thickness was calculated using the same allometric equations (Table 2).

\section{Results}

\subsection{Tree responses}

Most broadleaved trees survived the first post-fire year, while most conifers died (Table 3). Only $11 \%$ of the pine trees were alive by the end of the study period (5\% in $P$. pinaster and $15 \%$ in $P$. pinea). In contrast, $92 \%$ of the broadleaved trees were still alive by the end of the study period. Four years after wildfire, 5 of the 9 monitored broadleaved species had some mortality (ranging from 1 to $14 \%$ ), but only $C$. sativa presented very high mortality (83\%). In spite of the low mortality observed in most broadleaved trees, the majority were top-killed and regenerated only from the base of the trunk or roots. The remarkable exception was $Q$. suber for which none of the surviving individuals were top-killed. 
Most conifer mortality occurred within the first year following wildfire, and only an additional $9 \%$ died in the three subsequent years. In contrast, most (82\%) mortality on broadleaved trees occurred after the first year (Table 3 ).

\subsection{Mortality models}

Species group, bole char height and crown volume damaged were the most important variables influencing the probability of initial and delayed tree mortality (Table 4). The two fire severity indicators (PCH and TCD) were positively associated to tree mortality. Coniferous showed significantly higher mortality than broadleaved species. C. sativa suffered significantly greater mortality (not shown) than any of the remaining broadleaved species and thus a model differentiating this species was also included (Table 4). The ROC curves indicated that all selected models perform very well, with 92 to 98 percent concordance between predicted probabilities and observed outcomes.

We selected model M1 to be used in the validation phase, because TCD was not available on the validation subset and $C$. sativa species was not present. The full model goodness-of-fit test showed adequate fit of model M1 to the data. This model indicates that probability of mortality increases with char height, but the likelihood for broadleaved species survival is high and almost insensitive to this fire severity descriptor (Figure 1).

The area under the ROC curve (AUC) of the M1 validated model was 0.956, indicating a very good model performance, with close agreement between predicted and observed status one year following wildfires. The global accuracy (using a 0.6 probability threshold) was $93.2 \%$. For the validation dataset, $91.9 \%$ of the trees predicted to die were in fact dead one year following fire, and $93.8 \%$ of the trees were correctly predicted to survive (Table 5); the omission errors were $13.6 \%$ and $3.6 \%$ (i.e. the percentage of observed dead or alive trees that were not predicted by the model).

Additionally we tested different model fitting possibilities to predict delayed conifer mortality over the entire study period, using species as an additional variable (Mafra fire). The best model for conifers included one indicator of fire severity and a term for tree species (Table 6). As for the global mortality models, the fire severity descriptors were positively associated with the probability of mortality, but in this case TCD was a better predictor of mortality than $\mathrm{PCH}$. The species term was also significant in such a way that the probability of survival was higher for $P$. pinea (Figure 2).

For the delayed mortality of broadleaves, only the species factor showed to be significant. $C$. sativa, $Q$. coccifera, and $Q$. faginea were the only broadleaved species with a significant mortality, and so we fitted individual models for these species. For $Q$. faginea, none of the variables measured was a significant predictor of mortality. The only variable related with $C$. sativa mortality was $\mathrm{DBH}$, and the relationship was negative (model $\chi^{2}=6.218, P=0.013$; AUC $=0.800, P=0.037$ ). For $Q$. coccifera only the variable protected vs. unprotected was selected in the models (model $\chi^{2}=7.387, P=0.007 ; \mathrm{AUC}=0.717, P=0.062$ ). Concerning ungulate herbivory, and besides the logistic models, significant differences between trees protected from browsing and non-protected trees were observed in C. monogyna $\left(\chi^{2}=8.036\right.$, $P=0.0046)$ and in $Q$. coccifera $\left(\chi^{2}=4.957, P=0.0260\right)$.

\subsection{Top-kill models}

Bark thickness and char height were the most important variables affecting the probability of tree top-kill, and their influence was highly significant $(P<0.001$; Table 7$)$. The probability of top-kill increased with decreasing bark thickness and with increasing fire severity (Figure 3), as it was previously hypothesized. Few differences exist between top-kill models concerning one-year or four-years after fire, and both showed good performance (Table 7). As with mortality, very few broadleaves (only 5\%) had delayed top-kill. 
The TK1 model (Table 7 and 8) was selected for the validation phase. The validation dataset was constituted by 548 trees from three broadleaved species ( 403 were top-killed), monitored in four different wildfires. The model showed good performance, with AUC of 0.931. Cross-classification table evaluation showed a global accuracy of $85.4 \%$ (using a 0.7 probability threshold). Within this sample, $89.7 \%$ of the trees were correctly predicted to be top-killed one year following fire, and $73.0 \%$ were correctly predicted to regenerate from the crown.

\section{Discussion}

\subsection{General response patterns}

Most coniferous trees died as a consequence of the fire while the majority of broadleaved trees survived. Pine mortality was above $85 \%$, and ranged from 55 to $92 \%$ for the validation data set. However, pine mortality can be highly variable, ranging from 0 to $100 \%$ depending of fire characteristics and tree size (e.g. Rodrigo et al., 2007; Fernandes et al., 2008). For most conifers, including our two pine species, top-kill equals individual tree mortality, because they lack the ability to sprout from basal buds.

Variations in mortality can also occur in broadleaved species, although survival is often much higher than for conifers (e.g. Franklin et al., 2006; Quevedo et al. 2007). In the Mafra study area only $1 \%$ of all broadleaved trees were dead one year after fire, and this number increased to $8 \%$ by the end of the 4-years study period. These values are close to the one-year mortality found in the validation dataset (3\%). Despite the generally low mortality observed in broadleaves, most were top-killed and regenerated only from basal sprouts, meaning that several years or even decades will be required until the trees reach the pre-fire size.

\subsection{Factors affecting mortality and top-kill}

Besides the differences between the two main taxonomic groups (gymnosperms, angiosperms), fire injury indicators (crown volume scorched or consumed and bole char height) were major factors affecting post-fire mortality of coniferous and top-kill of broadleaved species (e.g. Ryan et al. 1988; Hély et al., 2003; Thies et al., 2006; Fernandes et al., 2008). Both $\mathrm{CH}$ and PCH were significant predictors of mortality and top-kill, although PCH understandably performed slightly better than $\mathrm{CH}$. Although char height does not necessarily quantify fire injury it can be effectively employed as a tree mortality predictor. Direct cambium examination should predict bole damage better (Ryan et al., 1988), however, a direct cambium assessment is less expedite and would have induced further injury to the burned trees (e.g. Thies et al., 2006).

In the case of conifers, crown volume damaged was the most important factor determining mortality. Sieg et al. (2006) found that including CVS and CVC separately in a mortality model for P. ponderosa resulted in greater predictive ability than considering TCD, but in our study the two models performed similarly. The mortality model for conifers suggests that for the same level of crown injury $P$. pinaster is more susceptible than $P$. pinea. Other studies also points to higher fire resistance of $P$. pinea in relation to $P$. pinaster and to other Mediterranean pines (Rigolot, 2004; González et al., 2007). Since these two species have similar bark thickness, we hypothesize that the higher $P$. pinaster mortality might be due to differences in crown architecture and to differences in susceptibility to insect attacks. Concerning crown architecture there are substantial differences between the two species, with $P$. pinea having the upper crown better protected from the heat flux (Rigolot, 2004; Fernandes et al., 2008). Concerning susceptibility to insect attacks, it is known that bark beetles can reach epidemic levels after fires and Vasconcelos et al. (2003) showed that Tomicus spp. in Portugal preferably attacks $P$. pinaster in comparison with $P$. pinea. In our study area both 
pine species presented signs of bark beetle attacks, but no measurements were made, thus hindering any conclusion.

Contrarily to conifers, none of the fire severity indicators was related to broadleaves mortality, which is consistent with other authors' findings (Stephens and Finney, 2002; Franklin et al., 2006). As broadleaves (resprouters) have buds located below ground, which are generally well protected from heat by the overlaying soil, the more commonly used fire severity indicators (related with crown and stem injury, but not with root injury) are more likely to be poorly or unrelated with the capacity of basal resprouting and survival. The usually low mortality rates of broadleaved species also contributes to the difficulty of fitting predictive models. However, we successfully developed models of top-kill suggesting a positive relation with $\mathrm{PCH}$ and a strong negative relation with BT.

Bark thickness (BT) did not significantly affect individual tree mortality but it was the most important factor in predicting top-kill in broadleaves. In other studies, $Q$. suber post-fire mortality has been shown to be much variable, mainly as a function of bark thickness (e.g. Barberies et al., 2003; Silva and Catry, 2006; Moreira et al. 2007). However, this species is a very special case because regular bark extraction for cork production (Aronson et al. 2009) makes this species particularly vulnerable to fire after debarking (Pausas 1997; Catry et al. 2009). On the other hand this species is recognized as the only European tree with above ground sprouting capability when the canopy is entirely burned (Pausas, 1997). In our study $Q$. suber was by far the most resilient to fire, as $99 \%$ of all trees resprouted from the crown, most likely because trees had not been debarked in the last decades. Concerning $F$. angustifolia, the low crown mortality observed (15\%) is probably due to the lower fire severity experienced, mainly due to their thicker bark, higher average height, and lower fire intensity, because most trees were located near streams or paths with lower fuel load. In our models, DBH and TH were also significant predictors of top-kill, but using these variables instead of BT resulted in lower predictive ability. Considering that BT is usually highly correlated with DBH and with $\mathrm{TH}$, our results are consistent with other studies that also reported these variables as good predictors of crown mortality (e.g. Regelbrugge and Conard, 1993; Hély et al., 2003).

Besides fire severity and the tree individual characteristics mentioned, there are other factors that can also determine the ability of post-fire trees survival such as herbivory, weather conditions and tree vigour (e.g. Ryan and Reinhardt, 1988; Whelan, 1995). In this study we hypothesized that ungulate herbivory could be an additional factor influencing the delayed mortality of top-killed broadleaves, because a regular consumption of basal sprouts would maintain the leaf area at low levels, hindering the adequate functioning of vital physiological processes (e.g. Canham et al., 1999). In fact, by the third year, cumulative impacts of deer on tree survival were apparent in C. monogyna and Q. coccifera. All dead $Q$. coccifera individuals had been browsed, and browsed C. monogyna trees experienced three times more mortality than unbrowsed individuals. In spite of the high resistance of resprouting species to repeated disturbances (Espelta et al., 2006), and although this effect killed only a small proportion of trees and was not observed in all broadleaved species, it is possible that the persistence of ungulate consumption will increase mortality in the future.

Weather conditions could also represent a cumulative factor of stress contributing to the observed delayed mortality. In 2005 the Portuguese mainland suffered the worst drought in the last 60 years (INAG, 2005). This can potentially explain the increased number of dead trees observed between 2005 and 2006, when some mortality occurred for the first time on $C$. monogyna and $Q$. coccifera ( $7 \%$ and $10 \%$, respectively), and doubled in $C$. sativa (from 40 to $80 \%$ ). These results emphasize the importance of understanding the interaction between fire and climate for predicting ecosystem responses and specifically the role of heat waves in increasing tree mortality. 
Concerning the very high mortality observed in $C$. sativa $(83 \%)$, we hypothesize that is because the study area is outside the optimal ecological area of distribution for this species (Capelo and Catry, 2007), and thus the monitored trees could be in weak physiological condition already before the fire. Tree vigour is considered to affect survival and crown-kill following tree injury (Ryan, 1982; Bond and van Wilgen, 1994), because trees are not likely to maintain a positive carbon balance if much leaf area is lost (Ryan and Reinhardt, 1988). However in the present study and like in most studies, no adequate measures of pre-fire tree vigour were available. Further post-fire studies on this species are required to understand whether their high mortality is due to local conditions or whether it is a general pattern of the species.

Some factors that can affect post-fire tree mortality are not accounted for by our models, such as insect or disease incidence. However our models may implicitly reflect the interactions between fire injury and insect or disease incidence, as both of them were present in several sampled trees. Despite these additional sources of variation, model performance was good, and the presented equations should be useful for the modeling and management of fire-injured stands.

\subsection{Implications for management}

The presented models perform similarly to other published models for different species and geographical locations (e.g. Regelbrugge and Conard, 1993; Rigolot, 2004; Hély et al., 2003; McHugh and Kolb, 2003; Hood et al., 2007). They were validated using independent datasets from other locations, suggesting some degree of applicability outside the study area.

Knowledge of fire effects on trees is valuable both for controlling fire injury and for predicting its consequences. The presented logistic regression equations rely on readily obtainable data, and are applicable over a wide range of tree sizes and species, and in a variety of stand conditions suffering moderate to severe burning. These models have several potential applications and can be useful to managers making pre-fire or post-fire decisions in mixed forest stands in the western Mediterranean Basin, where the studied species are present. They may be used for example when selecting species for forestation, or following fire, either to assess the probability of mortality or top-kill of individual trees when developing salvage guidelines, or to assess potential stand damages when considering different management alternatives.

\section{Acknowledgements}

The present study was funded by Fundação para a Ciência e a Tecnologia (project POCI/AGR/61407/2004) and by FFP (project Recuperação áreas ardidas). We also would like to acknowledge the Tapada Nacional de Mafra administration and personnel (especially Ricardo Paiva and Pedro Carrilho) for their logistic support, and to several people who supported field work during the 4-years study period, especially Tito Lopes, Amar Madoui, Ana Santos, Ricardo Silva, Rui Tujeira and Marjorie Kauffmann.

\section{References}

Aronson, J., Pereira, J.S., Pausas, J.G. (Eds.), 2009. Cork Oak Woodlands on the Edge: conservation, adaptive management, and restoration. Island Press, Washington DC. 315 pp.

Bond, W.J., van Wilgen, B.W., 1994. Fire and plants. Chapman and Hall, London.

Burnham, K.P., Anderson, D.R., 2003. Model selection and multi-model inference: a practical information-theoretic approach. Springer, New York. 
Capelo, J., Catry, F., 2007. A distribuição do castanheiro em Portugal, in: Silva, J.S. (Coord. Ed.), Do castanheiro ao teixo - As outras espécies florestais. Colecção Árvores e Florestas de Portugal. Público/ FLAD/ LPN, Lisboa, Vol. 5, pp. 79-86.

Catry, F.X., Moreira, F., Duarte, I., Acácio, V. 2009. Factors affecting post-fire crown regeneration of cork oak (Quercus suber) trees. Eur. J. For. Res. 128, 231-240.

Canham, C.D., Kobe, R.K., Latty, E.F., Chazdon, R.L., 1999. Interspecific and intraspecific variation in tree seedling survival: effects of allocation to roots versus carbohydrate reserves. Oecol. 121, 111.

DeBano, L.F., Neary, D.G., Ffolliott, P.F., 1998. Fire's effects on ecosystems. John Wiley \& Sons, Inc., New York.

Dylan, W.S., Knapp, E.E., Ferrenberg, S.M., Keeley, J.E., Caprio, A.C., 2006. Tree mortality from fire and bark beetles following early and late season prescribed fires in a Sierra Nevada mixed-conifer forest. Forest Ecol. Manag. 232, 36-45.

Espelta, J.M., Habrouk, A., Retana, J., 2006. Response to natural and simulated browsing of two Mediterranean oaks with contrasting leaf habit after a wildfire. Ann. Forest Sci. 63, 441-447.

Fernandes, P.M., Rigolot, E., 2007. The fire ecology and management of maritime pine (Pinus pinaster Ait.). Forest Ecol. Manag. 241, 1-13.

Fernandes, P.M., Vega, J.A., Jiménez, E., Rigolot, E., 2008. Fire resistance of European pines. Forest Ecol. Manag. 256, 246-255.

Franklin, J., Spears-Lebrun, L.A., Deutschman, D.H., Mariden, K., 2006. Impact of a high-intensity fire on a mixed evergreen and mixed conifer forests in the Peninsular Ranges of southern California, USA. Forest Ecol. Manag. 235, 18-29.

González, G.L., 2001. Los árboles y arbustos de la Península Ibérica y Islas Baleares. Ediciones Mundi-Prensa, Madrid.

González, J.R., Trasobares, A., Palahí, M., Pukkala, T., 2007. Predicting stand damage and tree survival in burned forests in Catalonia (North-East Spain). Ann. Forest Sci. 64, 733-742.

Hare, R.C., 1965. The contribution of bark to fire resistance of southern trees. J. Forest. 4, 248-251.

Hély, C., Flanningan, M., Bergeron, Y., 2002. Modeling tree mortality following wildfire in the southern Canadian mixed-wood Boreal forest. Forest Sci. 49 (4), 566-576.

Hood, S.M., McHugh, C.W., Ryan, K.C., Reinhardt, E., Smith, S.L., 2007. Evaluation of a post-fire tree mortality model for western USA conifers. Int. J. Wildland Fire 16, 679-689.

Hosmer, D.W., Lemeshow, S., 1989. Applied Logistic Regression. Wiley, New York.

IA, 2003. Atlas Digital do Ambiente. Available at http://www.iambiente.pt/atlas/est/index.jsp [Verified 30 October 2009]

INAG, 2005. Seca 2005: Relatório de balanço. Instituto da Água, Lisboa.

Krebs, P., Conedera, M., Pradella, M., Torriani, D., Felber, M., Tinner, W., 2004. Quaternary refugia of the sweet chestnut (Castanea sativa Mill.): an extended palynological approach. Veget. Hist. Archaeobot. 13 145-160.

Manel, S., Williams, H., Ormerod, S.J., 2001. Evaluating presence-absence models in ecology: the need to account for prevalence. J. Appl. Ecol. 38, 921-931.

McHugh, C.W., Kolb, T.E., 2003. Ponderosa pine mortality following fire in northern Arizona. Int. J. Wildland Fire 12, 7-22.

Miller, M., 2000. Fire Autecology. In: Brown, J. K., Smith, J. K. (Eds.), Wildland fire in ecosystems: effects of fire on flora. Gen. Tech. Rep. RMRS-GTR-42-vol. 2. Ogden, UT, U.S. Department of Agriculture, Forest Service, Rocky Mountain Research Station, pp. 9-34.

Moreira, F., Duarte, I., Catry, F., Acácio, V., 2007. Factors affecting post-fire cork oak survival in southern Portugal. For. Ecol. Manag. 253, 30-37.

Nunes, A.V., 2004. Estimativa das densidades para os grandes vertebrados da Tapada Nacional de Mafra, na nova situação, pós fogo 2003. First Degree Thesis, ISA - UTL.

Ordóñez, J.L., Retana, J., Espelta, J.M., 2005. Effects of tree size, crown damage, and tree location on post-fire survival and cone production of Pinus nigra trees. For. Ecol. Manag. 206, 109-117.

Paula, S., Arianoutsou, M., Kazanis, D., Tavsanoglu, Ç., Lloret, F., Buhk, C., Ojeda, F., Luna, B., Moreno, J.M., Rodrigo, A., Espelta, J.M., Palacio, S., Fernández-Santos, B., Fernandes, P.M., 
Pausas, J.G., 2009. Fire-related traits for plant species of the Mediterranean Basin. Ecology 90: 1420.

Pausas, J., 1997. Resprouting of Quercus suber in NE Spain after fire. J. Veg. Sci. 8, 703-706.

Peterson, D.L., 1985. Crown scorch volume and scorch height: estimates of post-fire tree condition. Can. J. For. Res. 15, 596-598.

Peterson, D.L., Ryan, K.C., 1986. Modeling postfire conifer mortality for long-range planning. Environmental Management 10 (6), 797-808.

Quevedo, L., Rodrigo, A., Espelta, J.M., 2007. Post-fire resprouting ability of 15 non-dominant shrub and tree species in Mediterranean areas of NE Spain. Ann. For. Sci. 64, 883-890.

Regelbrugge, J.C., Conard, S.G., 1993. Modeling tree mortality following wildfire in Pinus ponderosa forests in the Central Sierra Nevada of California. Int. J. Wildland Fire 3 (3), 139-148.

Rego, F., Rigolot, E., 1990. Heat transfer through bark - a simple predictive model, in: Goldammer, J.G., Jenkins, M.J. (Eds.), Fire in Ecosystem Dynamics: Mediterranean and Northern perspectives. SPB Academic Publishing, The Hague, pp. 157-161.

Rigolot, E., 2004. Predicting postfire mortality of Pinus halepensis Mill. and Pinus pinea L.. Plant Ecol. 171, 139-151.

Ryan, K.C., 1982. Evaluating potential tree mortality from prescribed burning, in: Baumgartner, D.M. (Ed.), Site preparation and fuels management on steppe terrain. Washington State University Cooperative Extension, Pullman, WA, pp. 167-179.

Ryan, K.C., Reinhardt, E.D., 1988. Predicting postfire mortality of seven western conifers. Can. J. Forest Res. 18, 1291-1297.

Ryan, K.C., Rigolot, E., Botelho, H.S., 1994. Fire response of Mediterranean vs. Western North American Conifers. In: Fire and its Relationship to Forest Health and Productivity Working Group, SAF National Convention, Indianapolis, USA, pp. 170-175.

Ryan, K.C., 1998. Analysis of the relative value of morphological variables in predicting fire-caused tree mortality. In: Viegas, D.X. (Ed.) Proceedings of the 3rd International Conference on Forest Fire Research - 14th Conference on Forest Fire Meteorology, ADAI, Coimbra, Vol II, pp. 15111526.

Sieg, C.H., McMillin, J.D., Fowler, J.F., Allen, K.K., Negron, J.F., Wadleigh, L.L., Anhold, J.A., Gibson, K.E., 2006. Best predictors for postfire mortality of ponderosa pine trees in the Intermountain West. Forest Sci. 52(6), 718-728.

Silva, J.S., Catry, F., 2006. Forest fires in cork oak (Quercus suber) stands in Portugal. Int. J. Environ. Stud. 63, 235-257.

Sokal, R.R., Rohlg, F.J., 1987. Biometry. W.H. Freeman and Company, New York.

Stephens, S.L., Finney, M.A., 2002. Prescribed fire mortality of Sierra Nevada mixed conifer tree species: effects of crown damage and forest floor consumption. For. Ecol. Manag. 162, 261-271.

SPSS, 2006. SPSS for Windows. SPSS Inc., Chicago.

Swets, J.A., 1988. Measuring the accuracy of diagnostic systems. Science 240, 1285-1293.

Thies, W.G., Westlind, D.J., Loewen, M., Brenner, G., 2006. Predicting delayed mortality of firedamaged ponderosa pine following prescribed fires in eastern Oregon, USA. Int. J. Wildland Fire $15,19-29$.

Tujeira, R., Morgado, R., 2007. Resposta de diferentes espécies florestais ao fogo - Um estudo de caso relativo aos incêndios de 2006 na região de Porto-de-Mós/Tomar. Technical Report. CEABN-ISA, Lisboa.

Vasconcelos, T., Branco, M., Nazaré, N., Kerdelhué, C., Sauvard, D., Lieutier, F., 2003. Host preference of Tomicus piniperda and $\mathrm{T}$. destruens for three pine species, in: Proceedings of IUFRO International Symposium Forest Insect Population Dynamics and Host Influences, Kanazawa, Japan,

Vesk, P.A., Westoby M. (2004). Sprouting ability across diverse disturbances and vegetation types worldwide. J. Ecol. 92, 310-320

Whelan, R.J., 1995. The ecology of fire. Cambridge University Press, New York. 
Table 1 - Characteristics of the trees ( $\mathrm{n}=1985,11$ species) used to develop and validate models to predict post-fire tree response

\begin{tabular}{lccccccccccc}
\hline \multicolumn{1}{c}{ Species } & \multicolumn{4}{c}{$\mathrm{DBH}(\mathrm{cm})$} & \multicolumn{2}{c}{$\mathrm{TH}(\mathrm{m})$} & \multicolumn{2}{c}{$\mathrm{BT}(\mathrm{cm})$} & \multicolumn{2}{c}{ TCD (\%) } & \multicolumn{2}{c}{ PCH $(\%)$} \\
Scientific name & & $\bar{x}$ & Range & $\bar{x}$ & Range & $\bar{x}$ & Range & $\bar{x}$ & Range & $\bar{x}$ & Range \\
\hline \multirow{2}{*}{ Castanea sativa } & 30 & 21.0 & $10-38$ & 7.5 & $4-11$ & 1.2 & $0.6-2.1$ & 99.7 & $90-100$ & 30.9 & $6-75$ \\
Crataegus monogyna & 133 & 17.8 & $5-41$ & 4.0 & $2-8$ & 0.9 & $0.4-1.6$ & 100 & 100 & 94.9 & $17-100$ \\
Eucalyptus globulus & 60 & 14.0 & $5-24$ & 11.5 & $6-16$ & 0.9 & $0.4-1.4$ & 100 & 100 & 36.4 & $10-100$ \\
Fraxinus angustifolia & 82 & 41.4 & $10-76$ & 11.3 & $5-18$ & 2.0 & $0.6-3.4$ & 89 & $65-100$ & 58.9 & $7-100$ \\
Olea europaea sylv. & 127 & 21.3 & $5-54$ & 4.5 & $2-10$ & 1.0 & $0.4-1.7$ & 100 & 100 & 98.6 & $25-100$ \\
Pinus pinaster & 56 & 50.9 & $23-101$ & 17.3 & $8-25$ & 5.4 & $2.9-9.2$ & 87.6 & $50-100$ & 78.9 & $32-100$ \\
Pinus pinea & 78 & 47.7 & $16-92$ & 12.4 & $3-17$ & 4.7 & $1.7-9.0$ & 92.2 & $50-100$ & 69.4 & $20-100$ \\
Pistacia lentiscus & 113 & 7.8 & $3-20$ & 2.4 & $1-5$ & 0.5 & $0.2-1.1$ & 100 & 100 & 97.2 & $33-100$ \\
Quercus coccifera & 120 & 12.8 & $4-30$ & 3.8 & $2-8$ & 0.6 & $0.2-1.2$ & 99.6 & $60-100$ & 99.0 & $42-100$ \\
Quercus faginea & 129 & 39.3 & $17-94$ & 8.9 & $3-17$ & 1.9 & $1.3-3.1$ & 99.3 & $75-100$ & 91.1 & $29-100$ \\
Quercus suber & 112 & 47.0 & $15-140$ & 8.8 & $3-16$ & 4.9 & $1.9-14$ & 99.3 & $60-100$ & 79.9 & $28-100$ \\
& & & & & & & & & & \\
\hline
\end{tabular}

$\overline{D B H}=$ diameter at breast height, $T H=$ total tree height, $B T=$ bark thickness (BT for all species but $Q$. suber is based on the equations presented in table 2), $T C D=$ total crown volume damaged, $P C H=$ maximum bole char height $n=$ total number of sampled trees, $\bar{x}=$ mean, $S D=$ standard deviation

Table 2 - Allometric relations between bark thickness (BT, $\mathrm{cm})$ and diameter at breast height (DBH, $\mathrm{cm}$ ) obtained from field measurements taken on 415 unburned trees from 10 species. Equations have the form $\mathrm{BT}=\mathrm{b}_{0} \mathrm{DBH}^{\mathrm{b} 1}$. $\mathrm{R}^{2}$, number of sampled trees and $\mathrm{DBH}$ range are also shown; all regressions are highly significant $(P<0.001)$

\begin{tabular}{lccccc}
\hline \multirow{2}{*}{\multicolumn{1}{c}{ Species }} & \multicolumn{2}{c}{ Coefficients } & \multirow{2}{*}{$\mathrm{R}^{2}$} & $\mathrm{n}$ & DBH range (cm) \\
\cline { 2 - 3 } Castanea sativa & $b_{0}$ & $b_{1}$ & & & $11-49$ \\
\cline { 2 - 3 } Crataegus monogyna & 0.061 & 0.970 & 0.76 & 41 & $3-42$ \\
Eucalyptus globulus & 0.072 & 0.874 & 0.77 & 40 & 1.227 \\
Fraxinus angustifolia & 0.062 & 0.934 & 0.93 & 41 & $3-101$ \\
Olea europaea sylv. & 0.196 & 0.539 & 0.57 & 42 & $3-97$ \\
Pinus pinaster & 0.103 & 1.023 & 0.90 & 44 & $2-56$ \\
Pinus pinea & 0.133 & 0.920 & 0.83 & 42 & $11-96$ \\
Pistacia lentiscus & 0.022 & 1.410 & 0.69 & 42 & $3-23$ \\
Quercus coccifera & 0.024 & 1.193 & 0.73 & 41 & $5-35$ \\
Quercus faginea & 0.241 & 0.567 & 0.84 & 42 & $4-108$ \\
\hline
\end{tabular}


Table 3 - Observed individual tree mortality by species in the first four years following Mafra wildfire $(n=755)$; percentage of top-killed trees (crown mortality) was almost the same in the four years after wildfire and the values presented concerns the fourth year

\begin{tabular}{|c|c|c|c|c|c|c|}
\hline \multirow[b]{2}{*}{ Species } & \multicolumn{4}{|c|}{ Cumulative mortality (\%) } & \multirow{2}{*}{$\begin{array}{c}\text { Top- } \\
\text { killed } \\
(\%)\end{array}$} & \multirow[b]{2}{*}{$\mathrm{n}(\mathrm{P})$} \\
\hline & $\begin{array}{c}1^{\text {st }} \\
\text { Year }\end{array}$ & $2^{\text {nd }}$ Year & $\begin{array}{c}3^{\text {rd }} \\
\text { Year }\end{array}$ & $\begin{array}{c}4^{\text {th }} \\
\text { Year }\end{array}$ & & \\
\hline Castanea sativa & 20 & 40 & 80 & 83 & 83 & $30(0)$ \\
\hline Crataegus monogyna & 0 & 0 & 7 & 7 & 93 & $75(46)$ \\
\hline Eucalyptus globulus & 0 & 0 & 0 & 0 & 100 & $60(0)$ \\
\hline Fraxinus angustifolia & 0 & 0 & 0 & 0 & 15 & $62(10)$ \\
\hline Olea europaea sylvestris & 0 & 0 & 0 & 0 & 97 & $78(44)$ \\
\hline Pinus pinaster & 84 & 88 & 95 & 95 & 95 & $56(0)$ \\
\hline Pinus pinea & 77 & 82 & 85 & 85 & 85 & $78(0)$ \\
\hline Pistacia lentiscus & 0 & 0 & 0 & 0 & 100 & $71(34)$ \\
\hline Quercus coccifera & 0 & 0 & 10 & 10 & 99 & $67(26)$ \\
\hline Quercus faginea & 2 & 3 & 3 & 14 & 89 & $89(56)$ \\
\hline Quercus suber & 1 & 1 & 1 & 1 & 1 & $89(0)$ \\
\hline
\end{tabular}

$\mathrm{n}(\mathrm{P})=$ total number of trees monitored during the four-year period (number of trees protected from deer browsing).

Table 4 - Logistic regression models to predict post-fire tree mortality. Models based on data from 11 species ( $n=1040$ trees for the first-year models, and $n=755$ for the fourth-year model)

\begin{tabular}{|c|c|c|c|c|c|c|c|c|c|c|c|c|}
\hline \multirow{2}{*}{ Model } & \multirow{2}{*}{$\begin{array}{l}\text { Years } \\
\text { since } \\
\text { fire }\end{array}$} & \multicolumn{5}{|c|}{ Coefficients } & \multirow{2}{*}{$\begin{array}{c}\text { Model } \\
\chi^{2}\end{array}$} & \multirow{2}{*}{ d.f. } & \multirow{2}{*}{$P$-value } & \multirow{2}{*}{ AUC } & \multirow{2}{*}{ AIC } & \multirow{2}{*}{$\mathrm{R}^{2}$} \\
\hline & & $b_{0}$ & $b_{1}$ & $b_{2}$ & $b_{3}$ & $b_{4}$ & & & & & & \\
\hline M1 & 1 & -7.151 & 6.657 & 0.028 & - & - & 506.95 & 2 & $<0.001$ & 0.935 & -434.9 & 0.77 \\
\hline M2 & 1 & -12.901 & 7.121 & - & 0.083 & - & 526.21 & 2 & $<0.001$ & 0.958 & -396.4 & 0.80 \\
\hline M3 & 1 & -10.551 & 8.717 & 0.052 & - & 7.330 & 563.84 & 3 & $<0.001$ & 0.981 & -319.2 & 0.83 \\
\hline M4 & 4 & -5.494 & 5.818 & 0.027 & - & 6.350 & 490.23 & 3 & $<0.001$ & 0.923 & -617.4 & 0.73 \\
\hline
\end{tabular}

Model coefficients: $b_{0}=$ constant; coefficients for the following variables: $b_{1}$ for Species Group (takes value 1 if species is coniferous, and 0 otherwise), $b_{2}$ for Maximum bole char height $(\%), b_{3}$ for Crown volume damaged $(\%), b_{4}$ for Castanea sativa (takes value 1 if species is $C$. sativa, and 0 otherwise); Model $\chi^{2}=$ Full model goodness-of-fit statistic, d.f. $=$ degrees of freedom, $P$-value $=$ significance level; AUC $=$ Area under ROC curve, $\mathrm{AIC}=$ Akaike information criteria; $\mathrm{R}^{2}=$ Nagelkerke $\mathrm{R}^{2}$.

Table 5 - Cross-classification table presenting the predicted and observed tree mortality. Based on a validation dataset of 945 trees from 4 species (using a 0.6 probability threshold)

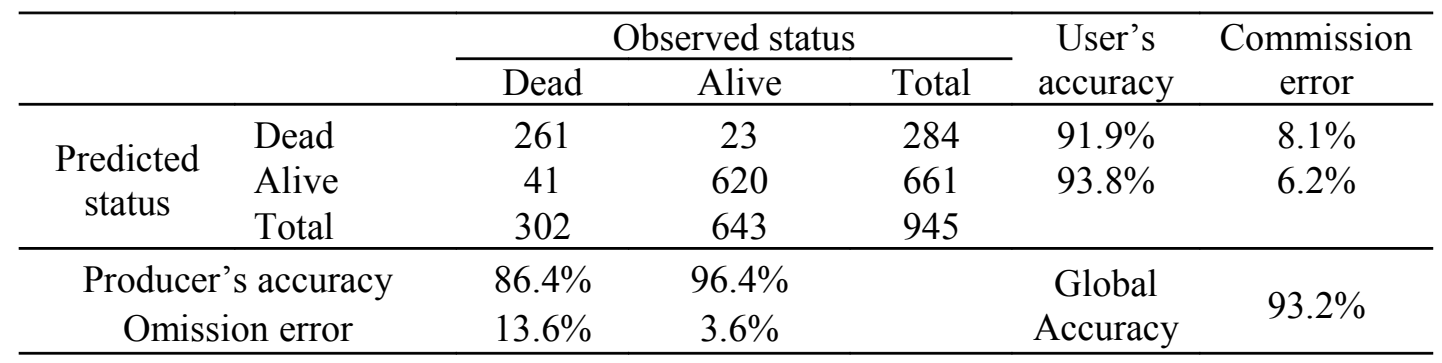


Table 6 - Logistic regression model to predict delayed (4 years after fire) mortality of $P$. pinaster and $P$. pinea. Variables are ordered by their decreasing importance on tree survival $(n=134)$

\begin{tabular}{llccccc}
\hline Effect & Variables & Coefficient & SE & Wald $\chi^{2}$ & d.f. & $P$-value \\
\hline$b_{0}$ & Constant & -7.152 & 1.928 & 13.766 & 1 & $<0.001$ \\
$b_{1}$ & TCD & 0.150 & 0.033 & 20.560 & 1 & $<0.001$ \\
$b_{2}$ & Species & -3.979 & 1.230 & 10.470 & 1 & $<0.001$ \\
\hline
\end{tabular}

Coefficients: $T C D=$ percentage of crown volume damaged (crown scorched + crown consumed), Species $=$ takes the value 1 for predicting $P$. pinea mortality and 0 for $P$. pinaster; $\mathrm{SE}=$ standard error, Wald $\chi^{2}=$ Wald chi-square statistic, d.f. $=$ degrees of freedom, $P$-value $=$ significance level; full model $\chi^{2}=46.33(P<0.001)$; area under ROC curve $=0.924(P<0.001)$.

Table 7 - Models to predict top-kill on 9 broadleaved species one and four years after Mafra wildfire ( $n=906$ trees for the first year model, and $\mathrm{n}=621$ for the fourth year model)

\begin{tabular}{|c|c|c|c|c|c|c|c|c|c|c|}
\hline \multirow{2}{*}{ Model } & \multirow{2}{*}{$\begin{array}{l}\text { Years } \\
\text { since } \\
\text { fire }\end{array}$} & \multicolumn{3}{|c|}{ Coefficients } & \multirow{2}{*}{$\begin{array}{c}\text { Model } \\
\chi^{2}\end{array}$} & \multirow{2}{*}{ d.f. } & \multirow{2}{*}{$\begin{array}{c}P \text { - } \\
\text { value }\end{array}$} & \multirow{2}{*}{ AUC } & \multirow{2}{*}{ AIC } & \multirow{2}{*}{$\mathrm{R}^{2}$} \\
\hline & & $b_{0}$ & $b_{1}$ & $b_{2}$ & & & & & & \\
\hline TK1 & 1 & 2.793 & -2.613 & 0.027 & 597.26 & 2 & $<0.001$ & 0.931 & -1010.5 & 0.69 \\
\hline TK2 & 4 & 3.415 & -2.750 & 0.033 & 437.14 & 2 & $<0.001$ & 0.949 & -557.8 & 0.74 \\
\hline
\end{tabular}

Coefficients: $b_{0}=$ Constant, $b_{1}=$ Bark thickness $(\mathrm{cm}), b_{2}=$ Maximum bole char height (\%); Model $\chi^{2}=$ Full model goodness-of-fit statistic, d.f. $=$ degrees of freedom, $P$-value $=$ significance level; AUC $=$ Area under ROC curve, $\mathrm{AIC}=$ Akaike information criteria; $\mathrm{R}^{2}=$ Nagelkerke $\mathrm{R}^{2}$.

Table 8 - Selected model (TK1) to predict broadleaves top-kill one year after wildfire

\begin{tabular}{llccrcc}
\hline Effect & Variables & Coefficient & SE & \multicolumn{1}{c}{ Wald $\chi^{2}$} & d.f. & $p$-value \\
\hline$b_{0}$ & Intercept & 2.793 & 0.366 & 58.318 & 1 & $<0.001$ \\
$b_{1}$ & BT & -2.613 & 0.200 & 170.063 & 1 & $<0.001$ \\
$b_{2}$ & PCH & 0.027 & 0.004 & 52.120 & 1 & $<0.001$ \\
\hline
\end{tabular}

Coefficients: $B T=$ Bark thickness $(\mathrm{cm}), P C H=$ Maximum bole char height $(\%)$; $\mathrm{SE}=$ standard error, Wald $\chi^{2}=$ Wald chi-square statistic, d.f. $=$ degrees of freedom, $P$-value $=$ significance level; full model $\chi^{2}=597.26$ $(P<0.001)$; area under ROC curve $=0.931(P<0.001)$. 
Catry et al. - 16

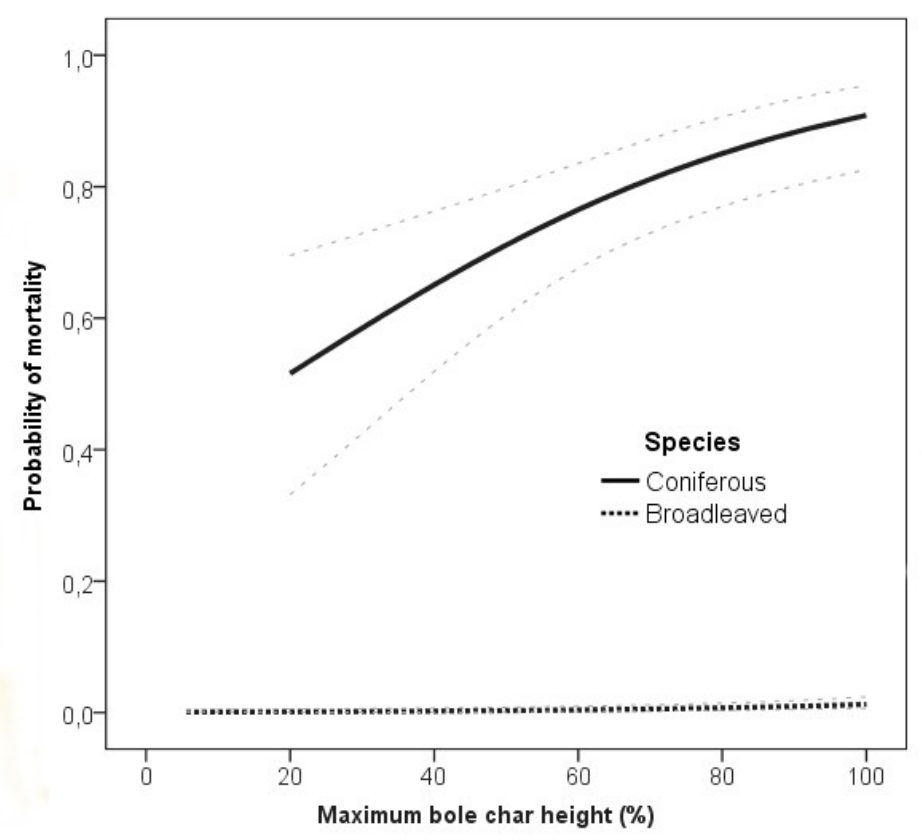

Fig. 1. Probability of individual tree mortality (with $95 \%$ confidence intervals) one year following wildfire as a function of the proportion of the bole charred (percent of tree height) for the two species group considered (coniferous vs. broadleaved trees).

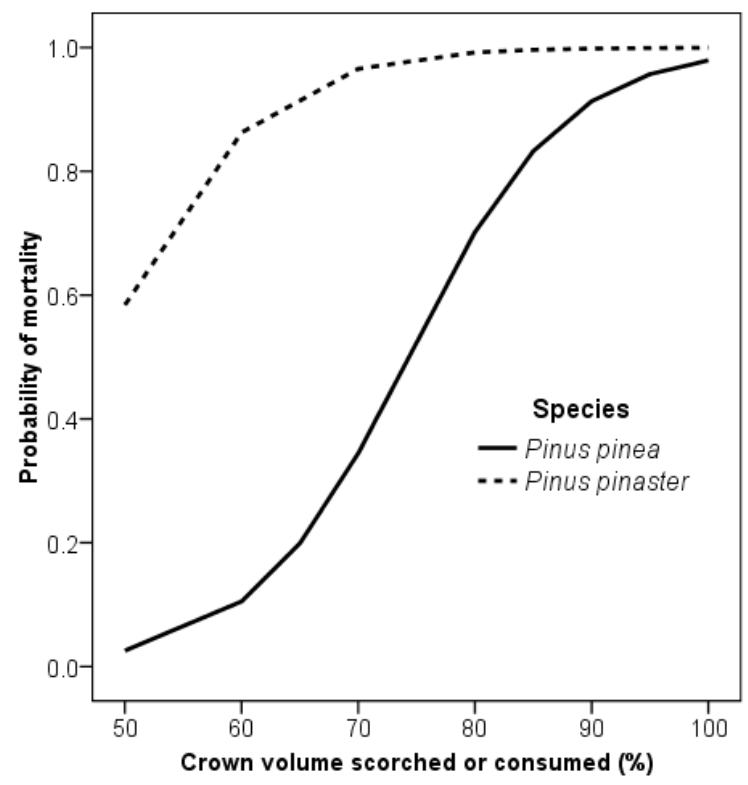

Fig. 2. Probability of mortality for Pinus pinea and P. pinaster four years following fire, as a function of total crown volume damaged (TCD). 


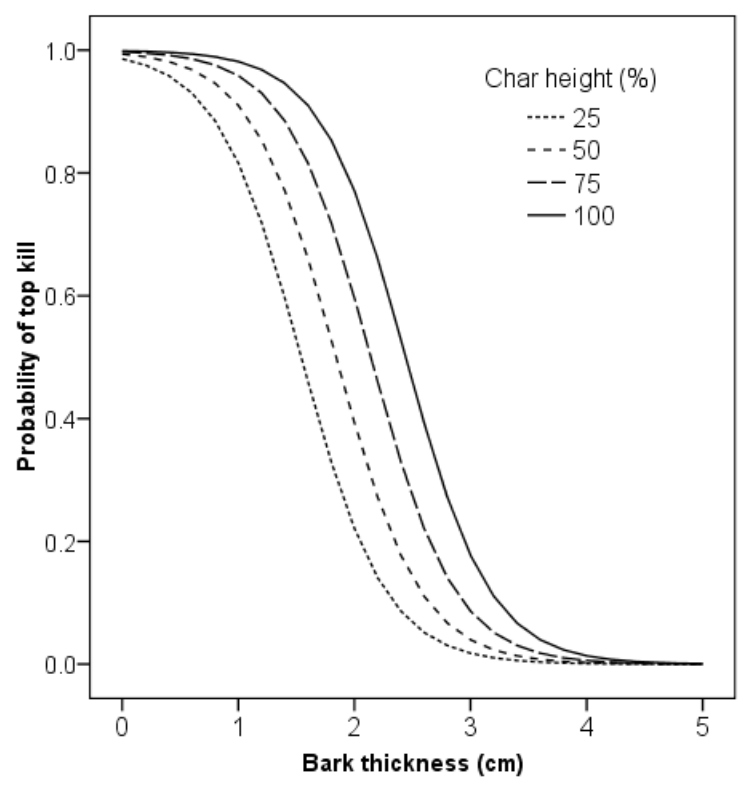

Fig. 3. Probability of top-kill (crown mortality) following wildfire on broadleaved species, as a function of bark thickness $(\mathrm{cm})$ and maximum bole char height $(\%)$. 